\title{
Economic Analysis of International Law
}

Contributions to the XIIIth Travemünde Symposium on the Economic Analysis of Law (March 29-31, 2012)

Ed. by Thomas Eger, Stefan Oeter and Stefan Voigt

[Ökonomische Analyse des internationalen Rechts. Beiträge zum XIII. Travemünder Symposium zur ökonomischen Analyse des Rechts (29.-31. März 2012).]

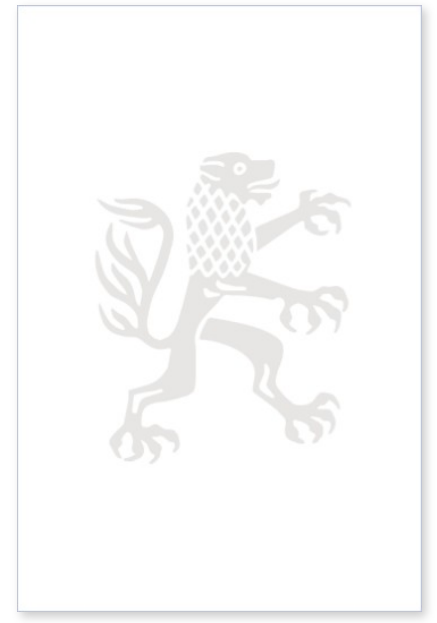

2014. XIII, 337 Seiten.

ISBN 978-3-16-153512-3

DOI 10.1628/978-3-16-153512-3

eBook PDF

ISBN 978-3-16-151894-2

fadengeheftete Broschur $94,00 €$
Veröffentlicht auf Englisch.

Die ökonomische Analyse des internationalen Rechts ist ein noch sehr junger, aber seit einigen Jahren wachsender und äußerst vielversprechender Forschungsbereich. Daher haben sich die Veranstalter des XIII. Travemünder Symposiums zur ökonomischen Analyse des Rechts vorgenommen, Ökonomen und Juristen aus europäischen und nicht-europäischen Ländern zusammenzubringen, um einige offene Probleme des internationalen Rechts zu diskutieren. Die Beiträge reichen von eher klassischen Themen, wie der Legitimität des Völkergewohnheitsrechts, zu sehr aktuellen Problemen wie dem Datenschutz im Internet, der Rolle von Söldnerheeren, dem Kampf gegen moderne Seeräuber, den Erfahrungen mit dem Internationalen Strafgerichtshof sowie dem Phänomen des »land grabbing".

Inhaltsübersicht

Stefan Oeter: The Legitimacy of Customary International Law - Georg von Wangenheim: Comment on Stefan Oeter Discussion on Stefan Oeter summarized by José Caiado - Stefan Voigt: The Economics of Informal International Law - An Empirical Assessment - Peter Lewisch: Comment on Stefan Voigt - Discussion on Stefan Voigt summarized by Christopher Kimmerle - Haksoo Ko: Law and Technology of Data Privacy: A Case for International Harmonization - Michael Fehling: Comment on Haksoo Ko - Discussion on Haskoo Ko summarized by José Caiado - Thilo Marauhn: Private Military Contractors - Mercenaries Outside the Scope of Law? - Discussion on Thilo Marauhn summarized by Jerg Gutmann Christopher R. Drahozal: Some Observations on the Economics of Comity - Dieter Schmidtchen: Comment on Christopher R. Drahozal - Discussion on Christopher R. Drahozal summarized by Jan Engelmann - Birgit Feldtmann: Fighting Maritime Piracy - On Possible Actions and Consequences - Max Gössler: Comment on Birgit Feldtmann - Discussion on Birgit Feldtmann summarized by Viola Prifti - Florian Jeßberger/Julia Geneuss: A Success? Reflections on the First Ten Years of the International Criminal Court - Eyal Benvenisti: Comment on Florian Jeßberger/Julia Geneuss - Discussion on Florian Jeßberger/Julia Geneuss summarized by Joseb Gudiashvili - Christian Kirchner: The European Constitutional Impossibility Theorem - Thomas Eger: Comment on Christian Kirchner - Discussion on Christian Kirchner summarized by Elif Erdemog/u Christian Häberli: Foreign Direct Investment in Agriculture: Land Grab or Food Security Improvement? - Laarni Escresa: Comment on Christian Häberli - Discussion on Christian Häberli summarized by Johannes Schwarze

Thomas Eger is a professor of Law and Economics at the University of Hamburg, Faculty of Law, Vice-Dean for Research and International Affairs and director of the Institute of Law and Economics.

Stefan Oeter is a professor of Public Law and International Law and director of the Institute for International Affairs at the University of Hamburg as well as chairman of the Historical Commission of International Society for Military Law and the Laws of War and member of the Permanent Court of Arbitration, Den Haag.

Stefan Voigt is a professor at the University of Hamburg and director of the Institute for Law and Economics at the University of Hamburg, fellow of the CESifo in Munich and connected to the International Centre for Economic Research (ICER) in Turin.

Jetzt bestellen:

https://mohrsiebeck.com/buch/economic-analysis-of-international-law-9783161535123?no_cache=1 order@mohrsiebeck.com

Telefon: $+49(0) 7071-923-17$

Telefax: $+49(0) 7071-51104$ 